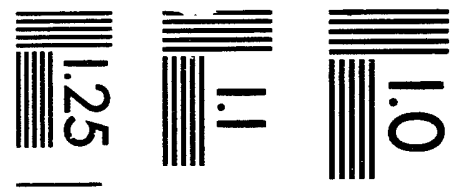

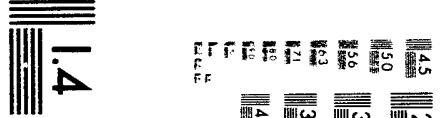

$$
\begin{aligned}
& \text { 三 }
\end{aligned}
$$

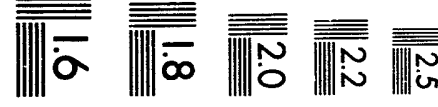



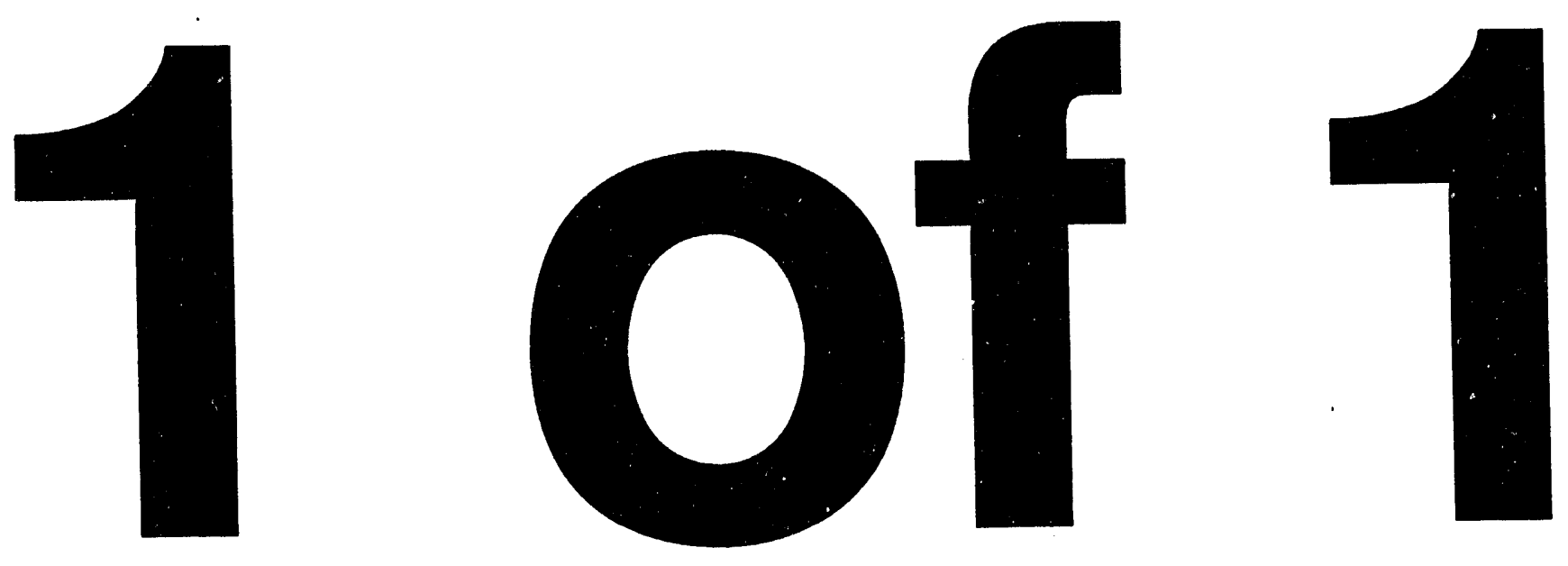


\section{HIGH LEVEL RADIOACTIVE WASTE GLASS PRODUCTION AND PRODUCT DESCRIPTION}

by

J. F. Sproull

Westinghouse Savannah River Company

Savannah River Site

Aiken, South Carolina 29808

S. L. Marra

C. M. Jantzen

A document prepared for:

Materials Research Society

at Boston, MA

from $11 / 29 / 93$ thru $12 / 3 / 93$

This paper was prepared in connection with work done under the above contract number with the U. S. Department of Energy. By acceptance of this paper, the publisher and/or recipient acknowledges the U.S. Government's right to retain a nonexclusive, royalty-free license in and to any copyright covering this paper, along with the right to reproduce and to authorize others to reproduce all or part of the copyrighted paper. 


\section{DISCLAIMER}

This report was prepared as an account of work sponsored by an agency of the United States Government. Neither the United States Government nor any agency thereof, nor any of their employees, makes any warranty, express or implied, or assumes any legal liability or responsibility for the accuracy, completeness, or usefulness of any information, apparatus, product, or process disclosed, or represents that its use would not infringe privately owned rights. Reference herein to any specific commercial product, process, or service by trade name, trademark, manufacturer, or otherwise does not necessarily constitute or imply its endorsement, recommendation, or favoring by the United States Government or any agency thereof. The views and opinions of authors expressed herein do not necessarily state or reflect those of the United States Government or any agency thereof.

This report has been reproduced directly from the best available copy.

Available to DOE and DOE contractors from the Office of Scientific and Technical Information, P. O. Box 62 , Oak Ridge. TN 37831; prices available from (615) $576-9401$.

Available to the public from the National Technical Informeion Service, U. S. Department of Commerce, 5285 Port Royal Rd., Springfield $V$ a $6 !$ 
High Level Radioactive Waste Glass Production and Product Description

James F. Sproull, Sharon L. Marra, and Carol M. Jantzen

Introduction

Chemical reprocessing of spent nuclear fuel and irradiated reactor targets reclaims about $99.5 \%$ of the uranium and plutonium present.' As a result of reprocessing, a variety of fission products, activation products, trace U/Pu, non-fuel components, and reprocessing chemical species remain. Defense high-level radioactive waste (HLW) is the term used for the radioactive waste generated as part of the U.S. defense effort. In the U.S. $400,000 \mathrm{~m}^{3}$ of defense HLW containing over 1 billion curies of radioactivity will be vitrified. ${ }^{2}$ This waste is currently stored as sludge, salt, and supernate liquid in an alkaline form in large underground carbon steel tanks at the Savannah River site (SRS) in South Carolina, and at the Hanford reservation in Hanford, WA. The sludge contains approximately $60 \%$ of the radioactivity, essentially all of the actinides, and most of the other long-lived species. The remaining $40 \%$ of the radioactivity (primarily from $\mathrm{Cs-137)}$ ) is in the soluble portion of the HLW. ${ }^{3}$ still another type of HLW is the mostly commercial HLW which is present in both mildiy alkaline and acidic forms at West valley, $N Y$, where it was generated as a result of reprocessing of spent commercial fuel rods.

With most of the HLW in the U.S. being stored in potentially dispersible, liquid form in underground tanks, ${ }^{2}$ efforts to change this waste into a more stable form, which will be suitable for eventual disposal in a geologic repository are being pursued. The HLW. will be subjected to a number of processing steps to reduce its volume and convert into canistered borosilicate glass waste forms.

A generic characterization of HLW at any site is difficult, since a number of different processes generated the wastes and different methods have been employed to prepare the wastes for storage. In some instances various types of waste have been blended in one storage tank. In general, the sludge at SRS contains high levels of aluminum, iron, and manganese, mostly as the hydroxides, and the soluble portion and the salt cake contain high levels of sodium and potassium nitrites, nitrates, etc. and most of the Cs-137. Although the HLW at Hanford does not contain the high levels of aluminum and manganese that the waste at SRS contains, it varies more extensively from tank to tank with, for example, some of it containing bismuth, phosphates, and also fluorides. HLW at West Valley is similar in composition to SRS waste, although it will be blended into only one waste type resulting in a single composition for vitrification. Both SRS and Hanford will have a number of different waste types to immobilize. 


\section{Selection of Borosilicate Glass}

Glass was recognized as being a promising medium for the immobilization of high-level radioactive wastes because of the recognized durability of silicate glasses and the capability of glass to incorporate many different elements - a necessity for nuclear waste immobilization. ${ }^{4}$ Glasses ranging from phosphates to aluminosilicates to borosilicates have been investigated since the middle 1950s. Jantzen employed a "systems approach" considering product performance and processing considerations simultaneously in selecting a suitable glass matrix, as shown in Table 1.5 For example, the low melting temperatures of phosphate glasses are offset by their corrosiveness and tendency to crystallize to less durable phases. The high chemical durability of aluminosilicates is offset by the high processing temperatures (glass viscosity) required to melt and form them and limited waste solubility. The process of elimination of various alternatives led to the selection of borosilicate glasses as the waste form of choice for most of the HLW in the U.S., although other glasses and crystalline ceramics are still being considered for certain applications.

\section{Processing Requirements}

The three primary processing requirements for nuclear waste glass are the liquidus temperature, the viscosity, and the glass redox state as shown in Table 2. The liquidus temperature must be below a certain maximum to prevent crystallization during melting or subsequent forming. Also to meet predetermined operating temperature limits, the viscosity must fall within a certain range dictated by the process. Too high of a viscosity will slow the melting rate, minimize homogenization during melting, and cause difficulty in pouring. Too low of a viscosity will cause excessive attack on the melter walls (metal or refractory). A processing requirement which is also a product requirement is the redox state of the glass which is determined by the melting temperature, the oxidizing/reducing condition of the melter feed, and the oxidizing/reducing conditions in the melter. The redox state of a glass can be indicated by any of several ratios including the ( $\mathrm{Fe}^{2+} /$ total $\left.\mathrm{Fe}\right)$ or the $\left(\mathrm{Fe}^{2+} / \mathrm{Fe}^{3+}\right)$ ratio. Waste glasses containing very low levels of variable valence state ions will not be redox sensitive.

From a processing standpoint the conditions in the DWPF melter must be slightly reducing to minimize foaming. 6,7 An $\left(\mathrm{Fe}^{2+} / \mathrm{Fe}^{3+}\right)$ target of $<0.1$ is preferred to prevent precipitation of noble metals. ${ }^{8}$ The redox states in the DWPF and West Valley melters will be controlled through the feed. The feed will be made more reducing by adding formic acid (DWPF) or sugar (WV) or more oxidizing by adding nitric acid (DWPF).

\section{Product Requirements}

The Department of Energy's Waste Acceptance-Systems Requirements 
Document (WA-SRD) defines requirements that spent fuel and borosilicate waste glass must meet for disposal in a repository. 9 The Waste Acceptance Product Specifications (WAPS) is a lower tier document to the WA-SRD which further defines requirements for the canistered borosilicate waste glass. ${ }^{10}$ The waste form must be borosilicate glass and must meet a short term durability requirement as measured by the Product: Consistency Test(PCT).11 The composition of the glass must be reported by the waste form producer but the selection of the composition is at the discretion of the producer. The producer will select the composition of a nuclear waste glass based on the particular balance of physical, chemical, and thermal properties required, the types of equipment being used for processing, and the types of waste being processed.

\section{Glass Durability}

The primary determinant of glass durability is the glass composition. A widely accepted model for relating glass durability to its composition is the Free Energy of Hydration Model. ${ }^{12}$ The basis for this model is a homogeneous, single phase glass.

\section{other Factors Affecting Durability}

For glasses containing variable valence cations such as Fe, the redox state of the glass has been shown to affect the durability of the glass.13.15 In general, reduced glasses tend to be less durable than oxidized glasses. Feng et al. reported that the normalized release of boron from a low alumina, poor durability glass (WV-205) increased 12-fold as the ( $\mathrm{Fe}^{2+} /$ total $\mathrm{Fe}$ ) ratio increased from 0.01 to $0.19 .^{15}$ Normalized release of boron and sodium into deionized water after 180 days was measured. on the other hand, for glass which was initially fairly durable (WVCM50), the leach rate increased by less than 2 -foid for a similar change in redox ratio. ${ }^{15}$

\section{Crystallization}

The crystallization of glass can also affect its durability. 13,16-27 The composition of the crystals, changes in the chemical composition of the matrix glass surrounding the crystals, or stresses at the glass/crystal interface. These effects individually or in combination can increase leaching. ${ }^{20}$ for instance, studies of SRS glasses partially crystallized to contain 1-10 vol.f crystals composed of spinels, nepheline, and acmite showed only minimal changes in short term leachability.20,28 Jantzen et al found that grain boundary interfaces preferentially increased leaching. ${ }^{20}$ For SRL 165 glass crystallized up to 30 vol. 8 , leachability as measured by the normalized boron release, increased by a factor of 3 compared to the uncrystallized glass. ${ }^{13,18,29}$ Turcotte studied the increase in leach rate of partially crystallized (4-7 wt.o crystals) glasses which were heat treated for up to one year (to $9-44$ wt. 8 crystals). ${ }^{16}$ The 
increase in leach rate was up to four times the original leach rate. It was concluded that the effect of crystallization on leach rate was less than that of glass composition changes. 20,30

Spinels, e.g. $\mathrm{NiFe}_{2} \mathrm{O}_{4}$, are one of several crystalline phases which have been found to form in borosilicate waste glasses if the glass is held below its liquidus temperature or cooled very slowly. The tendency of borosilicate waste glasses to crystallize during cooling after pouring can vary with the redox state of the glass. Bickford et al. ${ }^{18}$ and Jantzen ${ }^{13}$ found that at reduced oxygen fugacity, SRL TDS 165 waste glasses, containing 59 wt. $8 \mathrm{Fe}_{2} \mathrm{O}_{3}$ and $0.09 \mathrm{wt} .8 \mathrm{RuO}_{2}$ showed a lesser tendency to crystallize than when conditions were more oxidizing. In contrast, Jain et al. reported that more reduced glasses tended to be more crystallized than more oxidized ones, although the maximum crystallinity measured was only 1.4 vol.8.31 Buechele et al. reported that for West valley simulated waste glass SF-12 containing 11.3 wt. $\mathrm{Fe}_{2} \mathrm{O}_{3}$ but no noble metals, both very reduced $\left\{\left(\mathrm{Fe}^{2+} / \mathrm{Fe}^{3+}\right)>1.8\right\}$ and very oxidized (<0.01) glass crystallized less than intermediate redox state glasses $(0.45) .22$ Overall it appears that glass crystallization is affected somewhat by redox conditions, but the magnitude of the effect depends on the waste glass composition and cooling rate.

Redox conditions during melting can affect the precipitation of crystalline phases in the molten glass. Some waste components (e.g. noble metals $R u, R h$, and $P d$ ) do not dissolve in glass, but are encapsulated in the glass matrix. Copper, sulfates, selenates, tellurates, and phosphates can react to form conductive phases which can accumulate in the molten glass in the melter, reducing the electrical power available for melting. The formation of conductive phases can be slowed by controlling the redox state of the glass. Since the precipitated crystalline phases in the melter will either remain in the bottom of the melter or will be totally encapsulated in the glass, they will not affect the short term durability of the waste glass.

\section{Liquid-in-Iiquid Immiscibility}

Many publications discuss crystallization under the general catagory of phase separation. In this paper phase separation or immiscibility will encompass only the separation of the glass into two or more glassy phases. The cause of phase separation in glasses, e.g. a reduction in the thermodynamic free energy of the system, has been known for many years, and immiscibility in the $\mathrm{Na}_{2} \mathrm{O}-\mathrm{B}_{2} \mathrm{O}_{3}-\mathrm{SiO}_{2}$ system has been studied since the 1920s. For example, Turner et al.32 discussed leaching and consolidation of such phase-separated glasses in 1926 and Nordberg et al. received a patent for such glasses in 1934.33 A number of authors have reported the effects of phase separation on glass durability. ${ }^{34-36}$ The phase-separated glass may have an interconnected microstructure from either spinodal separation or a nucleation and growth process, or the phase separation may consist of droplets of one phase in a matrix of the other. The effucts of 
phase separation on the short term durability of glass are shown in Figure 1. Since the radionuclides tend to concentrate in the less durable phase, it appears to be best to formulate waste glass compositions to avoid phase separation.

The critical temperature and extent of phase separation for the $\mathrm{R}_{2} \mathrm{O}-\mathrm{B}_{2} \mathrm{O}_{3}-\mathrm{SiO}_{2}$ system vary with the alkali selection in the order: $\mathrm{T}_{c} \mathrm{Li}^{2}>\mathrm{T}_{c}$ Na $>\mathrm{T}_{c} \mathrm{~K}$, as shown in Figure 2. The extent of phase separation will also vary with different alkaline earths in the order $\mathrm{ZnO}>\mathrm{MgO}>\mathrm{CaO}>\mathrm{PbO}>\mathrm{BaO}$ as shown in Figure 3. The presence of $\mathrm{P}_{2} \mathrm{O}_{5}, \mathrm{~V}_{2} \mathrm{O}_{5}, \mathrm{MoO}_{3}$, or $\mathrm{WO}_{3}$ shifts the immiscibility region. ${ }^{37}$ Whereas $\mathrm{Al}_{2} \mathrm{O}_{3}$ and $\mathrm{GeO}_{2}$ suppress phase separation, $\mathrm{F}$ enhances it. 38

The Pacific Northwest Laboratory did an extensive composition/property study using ten compositional variables and found that more than half of the glasses studied were phase separated. ${ }^{39-40}$ Jantzen et al. developed a summary "ternary diagram" showing general compositional regions for Pyrex Vycor ${ }^{T H}$ glass, etc. as shown in Figure 4 for a composition without divalent oxides, since the SRS HLW is essentially free of CaO and Mgo. ${ }^{41}$ Although this figure is only approximate and the effects of alkaline earth oxides and other potential constituents are not shown, some general guidelines for a single phase waste glass can be formulated. These are that the alkali oxide content of a target waste glass should be greater than about 17 wt. $\%$, silicon dioxide plus aluminum oxide levels should be below 70 wt. 8 , etc. Engell et al.studied the phase separation tendencies of Swedish simulated alkali-borosilicate waste glasses ABS-39 and ABS-41 and concluded that although both were outside the immiscibility region, the ABS-41 glass was close to the boundary. ${ }^{42}$

\section{Summary and Conclusions}

Borosilicate glass will encapsulate most of the defense and some of the commercial HLW in the U.S. The resulting waste forms must meet the requirements of the WA-SRD and the WAPS, which include a short term PCT durability test. The waste form producer must report the composition(s) of the borosilicate waste glass(es) produced but can choose the composition(s) to meet site-specific requirements. Although the waste form composition is the primary determinant of durability, the redox state of the glass; the existence, content, and composition of crystals; and the presence of glass-in-glass phase separation can affect durability. The waste glass should be formulated to avoid phase separation regions. The ultimate result of this effort will be a waste form which is much more stable and potentially less mobile than the liquid high level radioactive waste is currently. 


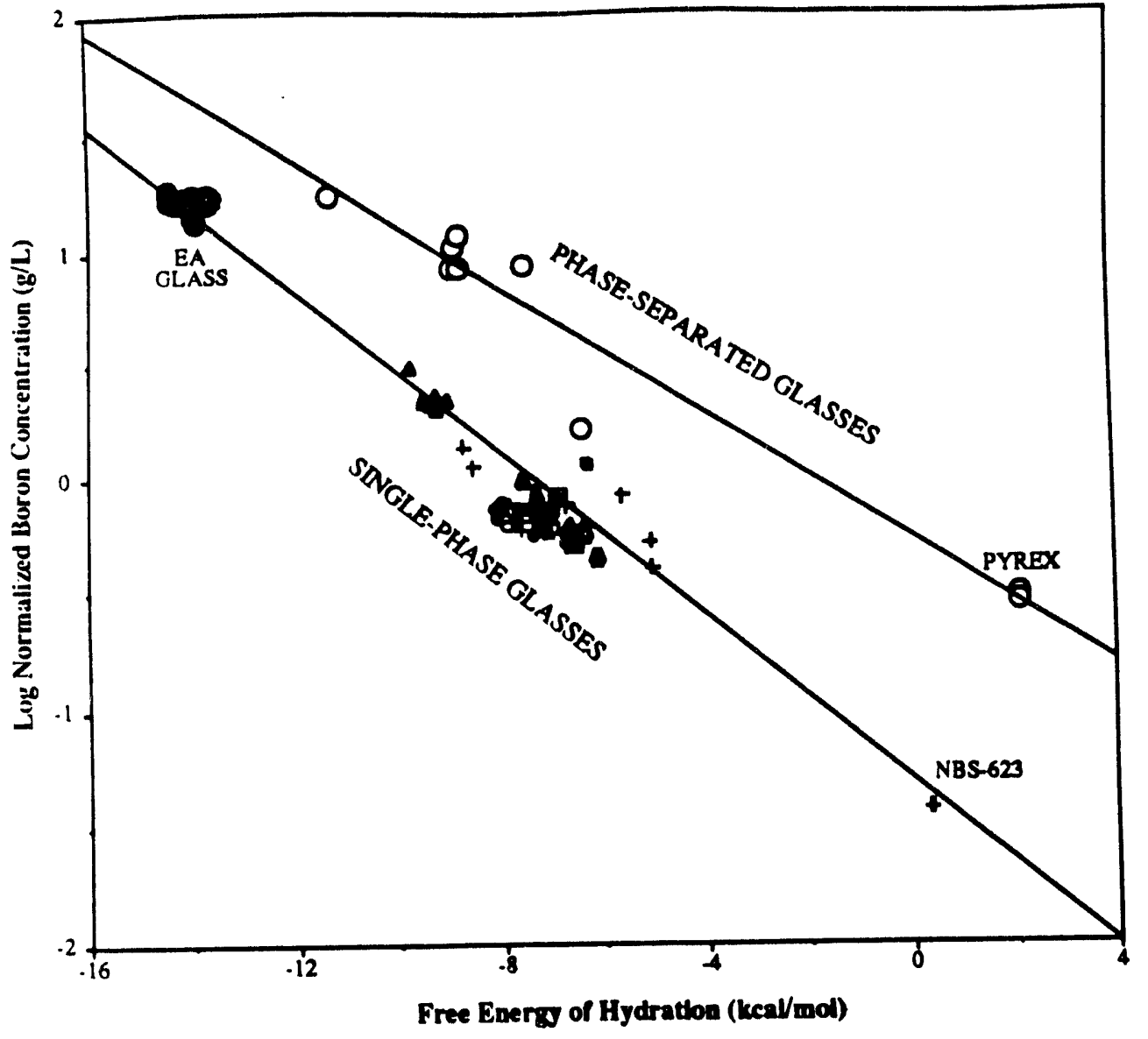

after Janzen ${ }^{41}$

Figure 1. Effects of Phase Separation on Glass Durability Modeling 


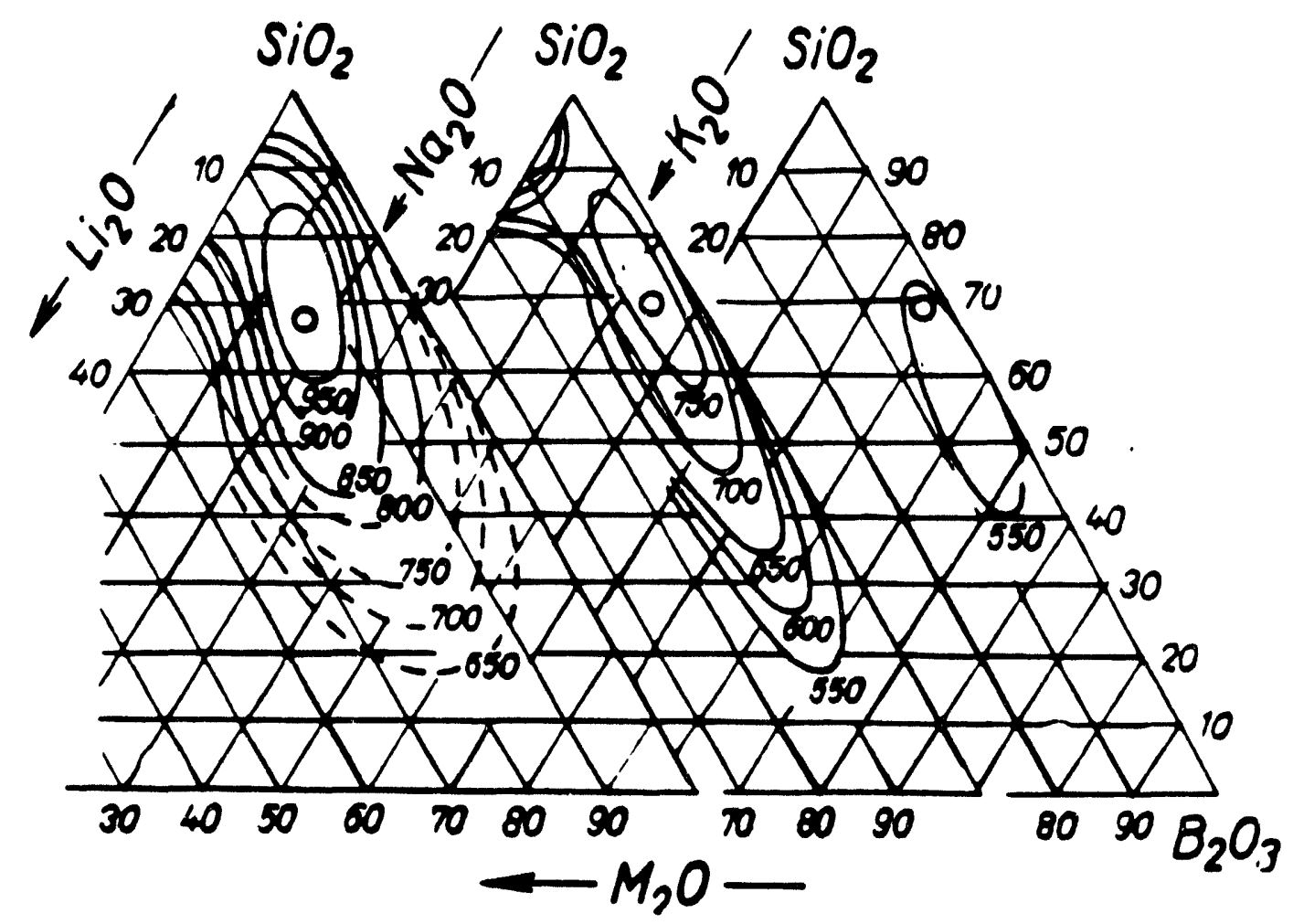
Figure 2. Effects of Alkall oxides on Phase separation of
Borosilicate Glass 


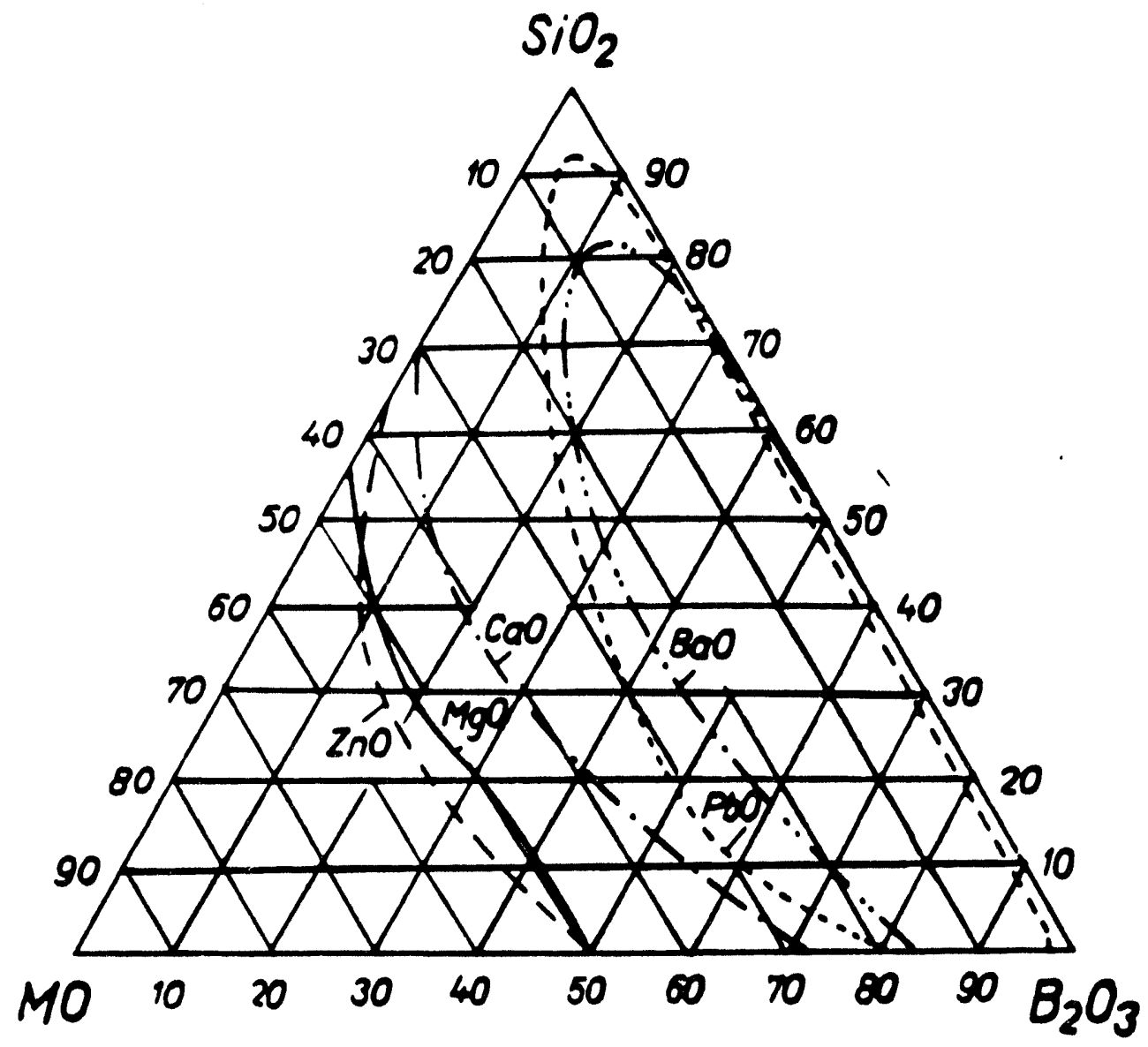

Figure 3. Effects of Divalent Oxides on Phase Separation of Borosilicate Glase

after Valdan ${ }^{4}$ 


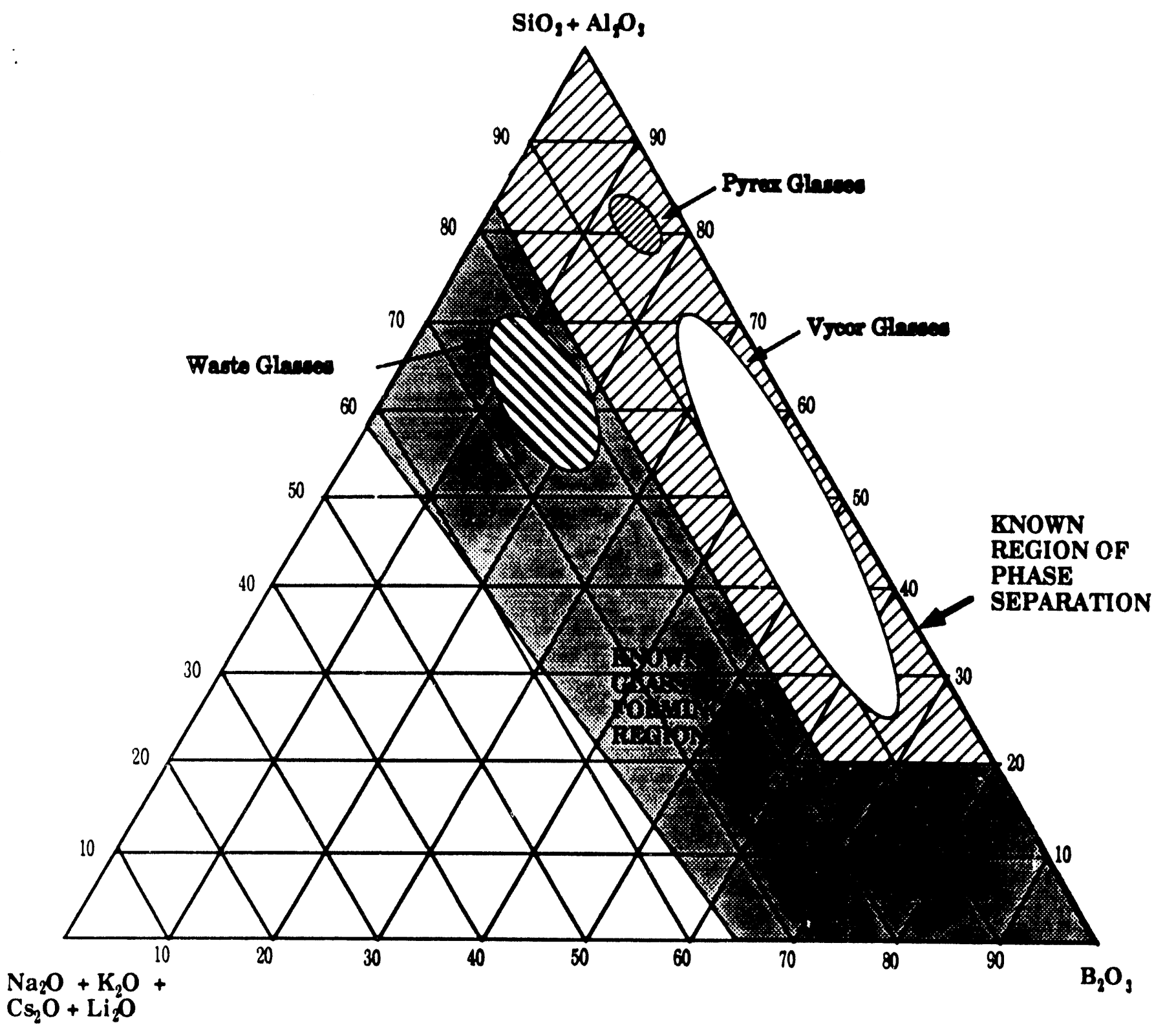

Figure 4. Composite Effects on Borosilicate Waste Glasses after Janzen 41 
Table 1. Systems Evaluation of Various Glass Types as Matrices for Nuclear. Waste Immobilization

Iype of Glass

Borosilicate Aluminosilicate Phosphote

Product Reliability

Chemical durability good

Thermal stability good

Mechanical stability good

excellent

good

good

\section{good \\ poor}

poor

Process Reliability

Melt temperature $\left({ }^{\circ} \mathrm{C}\right) \quad 1150$

Melt corrosivity overage

Waste soludility

Volatility

$\operatorname{good}(28-35 x)$

low

1350

average

fair(10x)

high

850-1050

high

low(5-15x)

- of hazardous species

Table 2. Glass Property Ranges for DWPF Glass

Property

Units

Viscosity

Poise

Liquidus Temp. ${ }^{\circ} \mathrm{C}$

Durability $\quad \mathrm{kcal} / \mathrm{mole}$

Redox state
Criteria

$20<$ visc. $<100$

$<1050$

$\Sigma G_{\text {hyd }}<-10.0$

$<0.1$ 
1. G.C. Wicks and D.F. Bickford, Savannah River Laboratory Report DP-1777, 1989.

2. Integrated Data Base for 1991: U.S. Spent Fuel and Radioactive Waste Inventories, Projections, and Characteristics, U.S. Dept. of Energy Report DOE/RW-006, Rev. 7, 1991.

3. R.G. Baxter, Defense Waste Processing Facility Wasteform and Canister Description, E.I. duPont de Nemours \& Co. Report No. DP-1606, Rev. 2, 1988.

4. J.M. White adn G. LaHaie, Atomic Energy of Canada Ltd. Report CRCE-591, 1955.

5. C.M. Jantzen, J. Non-Crystalline Solids, 84, 215-225, 1984 .

6. M.J. Plodinec, Proc. Symp. on High Temp. Materials Chem., The Electrochem., 201-209, 1982.

7. M.J. Plodinec, Savannah River Report No. DPST-86-213m 1986.

8. W.G. Ramsey and R.F. Schumacher, Westinghouse Savannah River Report WSRC-TR-92-484, 1992.

9. Waste Acceptance System Requirements Document, United States Department of Energy, DOE/RW-0351P, January, 1993.

10. Waste Acceptance Product Specifications for Vitrified HighLevel Waste Forms, U.S. Dept. of Energy, EM-WAPS, Rev. 0, February, 1993.

11. C.M. Jantzen, N.E. Bibler, D.C. Beam, W.G. Ramsey, and B.J. Waters, Westinghouse Savannah River Co. Report WSRC-TR-90539, January, 1992 .

12. C.M. Jantzen, Nuc. Waste Mgt. IV, Ceram. Trans, Vol 23, 37$51,1992$.

13. C.M. Jantzen, D.F. Bickford, and D.G. Karraker, Adv. Ceram. 8, 30-38, 1984 .

14. A. Manara, F. Lanza, G. Ceccone, G. Della Mea, and G. Salvagno, Mat. Res. Soc. Symp. Proc. 44, 63-72, 1985.

15. X. Feng, I.L. Pegg, E. Saad, S. Cucinell, and A. Barkatt, Ceram. Trans. 9 , 165-174, 1989.

16. R.P. Turcotte, J.W. Wald and R.P. May, in Sci. Basis for Nuc. Waste Mgt. II, Plenum Press, New York, 141-146, 1979.

17. B.M. Robnett and G.G. Wicks, Savannah River Laboratory Report DP-MS-81-60, 1981 .

18. D.F. Bickford and C.M. Jantzen, Mat. Res. Soc. Symp. Proc. 26, 557-566, 1984 .

19. C.J. Montrose, Aa. Barkatt, and P.B. Macedo, Mat. Res. Soc. Symp. Proc. 26, 741-754, 1984.

20. C.M. Jantzen and D.F. Bickford, Mat. Res. Soc. Symp. Proc. $44,135-146,1985$.

21. A.C. Buechele, X. Feng, H. Gu, and I.I. Pegg, Mat. Res. Soc. Symp. Proc. 176, 393-402, 1990.

22. A.C. Buechele, X. Feng, H. Gu, I.S. Muller, W. Wagner, and I.I. Pegg, Mat. Res. Soc. Symp. Proc. 212, 141-152, 1991.

23. A.C. Buechele, X. Feng, H. Gu, and I.L. Pegg, Ceram. Trans. 23, 85-94, 1991 .

24. A.C. Buechele, X. Feng, H. Gu, and I.L. Pegg, Nucl. Waste Mgt. IV, 85-94, 1991.

25. T.V. Palmiter, I. Joseph, and L.D. Pye, Mat. Res. Soc. Symp. Proc. 212, 153-158, 1991. 
26. S.I. Marra, R.E. Edwards, and C.M. Jantzen, High Level Rad. Waste Mgt. Conf. 1, Las Vegas, NV, 917-924, 1992.

27. S.L. Marra and C.M. Jantzen, Westinghouse Savannah River Co. Report WSRC-TR-92-142, 1992.

28. L.L. Hench, L. Werme, and A. Lodding, Sci. Basis for Nucl. Waste Mgt. V, 153-162, 1982 .

29. D.F. Bickford and C.M. Jantzen, J. Non-Crys. Sol., 84, 509$518,1987$.

30. J.W. Wald and J.H. Westik, in Ceramics in Nucl. Waste Mgt., Pacific Northwest Laboratory Report CONF-790420, 1979.

31. V.J. Jain and S.M. Barnes, Ceram. Trans. 23, 251-257, 1991.

32. W. Turner and F. Winks, J. Glass Tech., 10, 102, 1926.

33. M.E. Nordberg and H.P. Hood, U.S. Patent $2,106,744,1934$.

34. B.F. Howell, J.H. Simmons, and W. Haller, Ceram. Bull. 54(8), 707-709, 1975.

35. M. Tomozawa, in Treatise on Materials Science and Technology, Vol. 12, Academic Press, New York, 283, 1977.

36. T. Takamori and M. Tomozawa, J. Am. Ceram. Soc. 61 (11-12), 509-512, 1978 .

37. M. Tomozawa and R. Obara, J. Am. Ceram. Soc. 56(7), 378, 1980 .

38. D.R. Uhlmann and N.J. Kreidl, Glass: Science and Technology, Vol, 1 Glass-Forming systems, Academic Press, 176, 1983.

39. G.F. Piepel, P.R. Hrma, S.O. Bates, M.J. Schweiger, and D.E. Smith, First-order study of Property/Composition

Relationships for Hanford Waste Vitrification Plant Glasses, Rev. 0, Pacific Northwest Laboratory, Richland, WA, May, 1991.

40. P.R. Hrma and G.F. Piepel, Property/Composition Relationships for Hanford Waste Vitrification Plant Glasses-Preliminary Results Through CVS-II Phase 2, Pacific Northwest Laboratory, Richland, WA, p 12.45, Sept., 1992.

41. C.M. Jantzen and R.F. Schumacher, "Glass Phase Separation; Implications for Waste Glass Durability Modeling, Am. Ceram. Soc. National Meeting, Spring, Cincinnati, OH, 1993.

42. J.E. Engell and G. Roed, Sci. Basis for Nucl. Waste Mgt., 609-617, 1982 .

43. J.W. Cahn, Acta Metall., 9, 795-801, 1961.

44. J. Chem. Phys., 42, 686-693, 1965.

44. J. Voldan, XIth International Congress on Glass, Vol. II, 57, 1977 . 


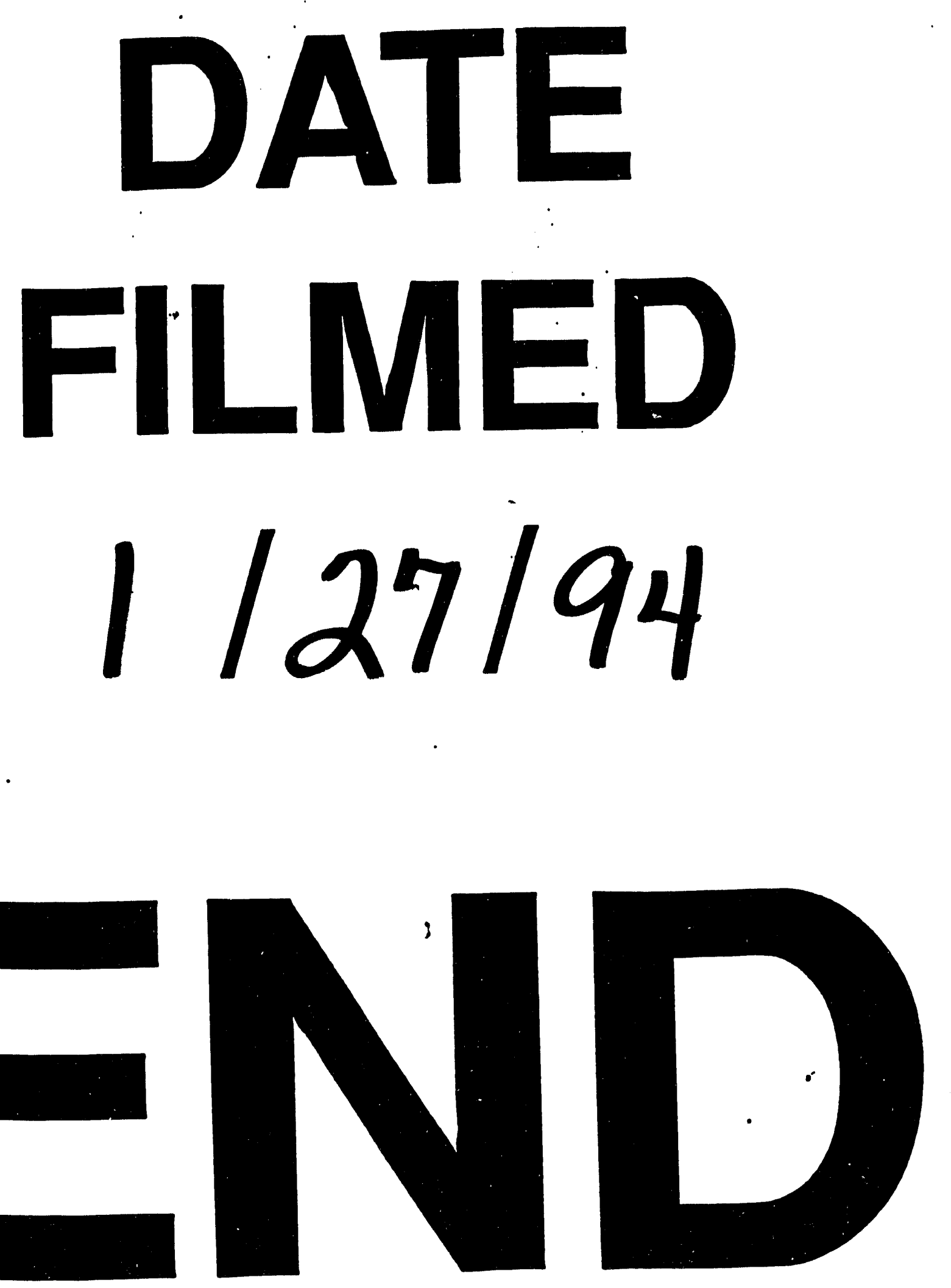


